\title{
A GRAVITÁCIÓS MODELL ALKALMAZÁSI LEHETŐSÉGEI A TELEPÜLÉSEN BELÜLI MOZGÁSOK TANULMÁNYOZÁSÁRA
}

\author{
(The possibilities to apply the gravity modell for investigation the \\ movemnets inside the city)
}

NAGY GÁBOR

\section{A gravitációs modell alkalmazási területei}

A fizikai analógián alapuló - a newtoni tőmegvonzást a gazdasági és társadalmi térfolyamatokra alkalmazó - gravitációs modell a húszas-harmincas évek fordulóján jelent meg a USA-ban (Reilly 1929), klasszikus alkalmazását a nagyvárosi vonzásterületek valamilyen szempontú lehatárolása jelentette. A szélesebb körủ alkalmazásra, illetve a modell matematikai hátterének finomítására a második világháború befejezéséig kellett várni. Az ötvenes évektől az európai (elsősorban a nyugat- és észak-európai) geográfia és az alakuló regionális gazdaságtan fedezi fel a módszert. A modell alkalmazása során nagy számban szúletnek az *esettanulmányok, $\mathrm{s}$ az ötvenes és hatvanas években megfogalmazódnak az első kritikák (Klöpper 1953, Green 1951, 1958), megjelennek a továbbfejlesztett, finomított matematikai apparátust felvonultató kutatási eredmények (Thorwid 1963). Megállapítják, hogy a modell a legkevésbé a nagy várossürüségú, erősen és egyenletesen benépesült országok, nagytérségek vizsgálatára alkalmas, ugyanakkor a valóságot jól közelítő eredményekhez vezet nagy területü, alacsony népsúrúségủ és ritkás városi hálózattal bíró régiók elemzésekor.

Az ötvenes-hatvanas évek fordulóján indul el a gravitációs modell alkalmazása kisebb téregységek, általában nagyvároson belüli mozgásfolyamatok vizsgálatában (Hansen 1959, Isard 1960), ám a kezdeményezés nem talált túl kedvezỏ fogadtatásra a szakmában, így a hetvenes évek elejére ez az irányzat lényegében kifullad. Módszertanában azonban legalább annyira kiforrottnak tekinthető, mint a nagytérségi kutatások matematikai apparátusa (Hoover 1971)

A gravitációs modellek alkalmazásának nagy korszakát a hetvenes évtized jelenti, ekkor jelennek meg a legnagyobb számban az esettanulmányok, folynak szakmai viták a módszer alkalmazhatóságáról, s készülnek el a máig legfontosabb összefoglaló munkák (ErlanderStewart 1980, Karlquist-Lundqiust-Snickars eds., 1975, Williams-Senior 1978, Wilson 1974, 1981). A hetvenes évek közepétől az újabb matematikai-statisztikai módszerek, illetve aź évtized végétől elinduló behaviorista forradalom háttérbe szorították a gravitációs modellek alkalmazását. Újbóli megjelenésük a földrajzi és a regionális gazdaságtani munkákban a kilencvenes évek elejére tehető, föként skandináv, német és brit kutatók alkalmazzák. Az alkalmazási területek közül az infrastrukturális rendszereken 
történỏ mozgások modellezése, a területhasznosítás, az alapfokú intézményekbe történő mozgások és a térségen belüli vonzásviszonyok feltárása a legfontosabbak.

A kelet-közép-európai geográfiában a hatvanas évek elejétöl követhető a gravitációs modellek alkalmazása, s nem véletlen, hogy a legkorábbi, illetve a legfontosabb alapmüvek is lengyel szerzők tollából születnek (Chojnicki-Wrobel 1963, Korcelli 1975, Kostrubiec és szerzötársai 1975). A lengyel munkákban a modell nagytérségi alkalmazásaira találunk példákat, több esetben egyedileg kidolgozott matematikai formulákkal dolgoztak, nem egyszerủen alkalmazták a kidolgozott képleteket.

A hazai földrajztudományban a gravitációs modell első leírása Beluszky Pál nevéhez köthető (Beluszky 1967), aki a későbbiekben is a modell alkalmazásának egyik hazai úttörỏje maradt (Beluszky 1974, 1981). Munkáiban a gravitációs modell nagytérségi alkalmazásait követhetjük nyomon. A hetvenes évek végén újabb kísérletek történnek a modell alkalmazására, részben más módszerek kiegészítéseként (Papp 1981), részben kombinálva az újabb faktoranalizis eredményeivel (Lackó 1978). A módszertani összefoglalás, és az alkalmazás további területeinek leírása a nyolcvanas évek elején (Sikos 1984) már újabb módszerek elöretörését, $\mathrm{s}$ a gravitációs modell háttérbe szorulását jelentette.

A utóbbi években országos szintủ vizsgálatokban alkalmazták a módszert (Pálné 1994, Nagy E.-Nagy G. 1995), melyek a regionális centrumok, a nagyvárosok vonzás-területének meghatározására elevenítették fel a gravitációs modellt.

\section{A modell alkalmazása a városon belüli jelenségek leírására - a györi kiskereskedelem példáján}

Jelenlegi munkánkban megkíséreljük alkalmazni a gravitációs modellt egy város terén belüli mozgásfolyamatok bizonyos típusának feltárására. A modell azt vizsgálja, hogy az egyes városrészek között milyen intenzitású kapcsolatok alakultak ki a győri kiskereskedelemben.

Módszertani szempontból munkánk során több nehézségbe is ütköztünk. Elsőként említhető a kiskereskedelmi funkció szempontjából eltérô karakterü városrészek lehatárolása volt, melyet a társadalom ơsszetétele, a beépítés módjai és a kiskereskedelmi szervezetek eloszlása alapján tettünk meg. Az egyes városrészek a gravitációs modell szempontjából még nem értelmezhetök, így szükséges volt a városrészek súlypontjainak meghatározására, mert ezután már pontként kezelhettük óket. Végül két szempont szerint készítettük el a súlypontokat, egyrészt a kereskedelmi szervezetek forgalmának földrajzi eloszlása szerint, másrészt a népesség térbeli eloszlása alapján.

A második fontos probléma, amit le kellett küzdeni, hogy nem álltak rendelkezésre részletes adatok a kiskereskedelmi egységekről az általunk lehatárolt városrészekre vonatkozóan. Kétféle adatbázist tudtunk ilyen bontásban elóállítani; a cégek árbevételét 1992-re és 1993-ra (az APEH adatai segítségével), valamint a kiskereskedelmi alapterületet az 1993-as év végi állapot szerint (a városi ÅRT adatainak felhasználásával). A tényleges elemzésben az 1993-as árbevételt használtuk, s kiszámítottuk a városrészek lakosságának számát 1993 év végére (a KSH segítségével). A népességi és az alapterületi adatok lényegében torzítás nélkül előállíthatók voltak az általunk készített városrészi beosztásra, ám az árbevételi adatok esetében komolyabb gondok vetődtek fel. $\mathrm{Az}$ adatbázis minden esetben a cégközponthoz rendelte az árbevételeket, így jelentős 
aránytalanságokat kellett kiküszöbölni a használhatóság érdekében. Szerencsére a legnagyobb kéttucat kiskereskedelmi vállalkozás vezetóivel készített személyes interjúk segítségével a helyi láncok szinte mindegyikénél szét lehetett választani a bevételi adatokat az egyes egységekre, ezek pedig egyértelmúen besorolhatók voltak valamely városrészbe. További gondot jelentett a lakáscímre bejelentett vállalkozások illetve a tényleges boltok elhelyezkedésében meglévő különbségek kezelése. Szerencsére a kisebb alapterületủ egyéni vállalkozás, vagy betéti társaság formájában müködő cégek túlnyomó többsége (terepi felmérések szerint 88-96\%-a) az adott városrészben helyezkedik el, másrészt e kisebb kereskedelmi egységek árbevétele egységenként viszonylag csekély, a városrész egészét tekintve az arányokat csak árnyalatnyival módosítja. Lényegében tehát az árbevételi adatok is felhasználhatók a városrészenkénti vizsgálatok elvégzésére.

A harmadik módszertani problémák harmadik csoportját a megfelelő képlet kiválasztása, illetve a tapasztalati együtthatók meghatározása jelentették.

Alapképletként az $I_{i j}=G *\left(P_{i} * P_{j}\right) / d_{i j}{ }^{b}$, a város belső szerkezetének vizsgálatára használt formulát választottuk, ahol:

$\mathrm{I}_{\mathrm{ij}} \quad$ az i-edik és j-edik városrész közötti kapcsolat intenzitását mutatja,

$\mathrm{P}_{\mathrm{i}}$ és $\mathrm{P}_{\mathrm{j}}$ az i-edik és j-edik vảrosrészek "súlya",

$\mathrm{d}_{\mathrm{ij}} \quad$ az i-edik és j-edik városrész közötti távolság,

b a tapasztalati hatványkitevö,

G a tapasztalati gravitációs konstans.

A képlet lényegében a Reilly-féle elsőként használt módszer Isard és a Carrell-Bevis szerzőpár által módosított alakja.

A tapasztalati konstans meghatározásakor az eredmények értelmezése nem követelte meg szorzószám alkalmazását, így $\mathrm{G}=1$ értéket használtuk.

A "b" kitevő meghatározásakor több úton indultunk el. Az első modellszámításhoz a klasszikus távolságfogalomnál alkalmazott négyzetes kitevőt használtuk. A második esetben a Hoover által javasolt módositásokat alkalmaztuk, amelyek az egyes városrészek elérhetőségét, illetve azok központi, vagy periférikus fekvését jelzik. Ennek megfelelően:

1,5 a kitevő, ha a mozgás a belvárosba irányul,

2,5 a kitevő, ha a belvárosból kifelé történik a mozgás,

2,5 a kitevó, ha a csatolt települések felé irányul a mozgás és

2 a kitevö, ha a csatolt települések és a belváros nélküli várostesten belül mozgunk. A harmadik alkalmazásban az utóbbi kitevő értékét módosítottuk (csökkentettük) a tömegközlekedés járatsủrüségének figyelembevételével.

A távolságfogalom meghatározásakor szintén több alternatívát vettünk figyelembe. Az első modellben a tömegközlekedés járatidejének percben kifejezett értéke volt a városrészek korábban meghatározott súlypontjai közötti távolság mérésének alapja. Alapfeltevésünk az volt, hogy a vásárlások nagyobb hányada a tömegközlekedési hálózaton végzett mozgások során következik be. A második, illetve a harmadik modellben a fizikai távolsággal számoltunk. Itt abból indultunk ki, hogy minden városon belüli mozgás időigénye - legyen az személy- vagy tömegközlekedés - nagyjábanegészében a fizikai távolsággal arányos, így a távolság abszolút mérőszámai jól közelítik a városrészek elérhetőségéhez szükséges idö arányait.

Az egységek súlyának kifejezésére a városrészekre kiszámolt kiskereskedelmi adatokat használtuk fel. Az elsỏ modellben a súlyokat az egyes városrészek árbevételi adatai 
szolgáltatták (milliárd forintban kifejezve), a második modellben a kiskereskedelmi alapterület (ezer $\mathrm{m}^{2}$-ben), mig a harmadik számításnál az alapterület és a városrész népessége (ezer fö) szerepelt. Az utóbbi megközelítés szakmai szempontból is újdonságot jelent - legalábbis a hazai szakirodalomban -, hiszen a képletben megjelenö i-edik és j-edik városrész súlyát egészen más típusú adatok szolgáltatjảk. Ez a megközelítés abból a feltételezésből következett logikusan, hogy egy városrész kiskereskedelmi hálózata (amit a modellben a kiskereskedelmi egységek alapterületével, mint indikátorral közelítettünk meg) a többi városrész népességére, mint potenciális vásárlókra gyakorol vonzeröt, sokkal inkább, mint a másik városrész kiskereskedelmi egységeire!

\section{A modellszámítás folyamata, az egyes megközelítések elönyei és hátrányai}

Az első munkafázis a távolságmátrix elóállitását jelentette mindhárom megközelítésben. Az elsỏ modellben bármely két városrész között a távolság szimmetrikus volt, hiszen a b kitevő minden esetben konstans (négyzetes). A második és harmadik modellben aszimmetrikus távolság a belváros-nem belváros, illetve a csatolt telepulés-nem csatolt település viszonylatban várható, a belváros és a peremek nélkuli várostest esetében a távolságok minden esetben páronként azonosak lesznek, hiszen a b kitevő értéke mindig 2.

A vonzási mátrix kiszámítása, illetve ezzel párhuzamosan a kritikus intenzitási szint meghatározása volt a következő munkafázis. Az első modellben bármely két városrész között szimmetrikus vonzás alakult ki, köszönhetően a mutatóknak és az alkalmazott formulának. A második esetben a belváros és a többi városrész, a csatolt városrészek és a többi városrész esetében a vonzás aszimmetrikus, mégpedig a belvárosba történő mozgás minden estben erösebb, mint a kifelé irányuló párja, illetve a csatolt településekre történó kimozgás minden esetben kevésbé intenzív; mint a befelé irányuló komponens. A harmadik számitásban lényegében nem várható szimmetrikus vonzás, hiszen az eltérö karakterü súlyok használata (alapterület és népesség) ezt nem segíti elö, ráadásul a távolságnál alkalmazott módosított kitevők is korlátozzák a lehetséges szimmetrikus vonzáspárok kialakulását. A vonzásmátrix kiszámitása után egységesen a 10 feletti intenzitási értékeket tekintettük szignifikánsnak, így a három modell által feltárt kapcsolatok összehasonlíthatókká váltak.

\section{Értékelés}

A vonzási mátrixok alapján mindhárom esetre elvégeztük a kartográfiai ábrázolást, majd a kapott eredmények kiértékelését ( 1 . ábra), s igyekeztünk levonni a hasznosítható következtetéseket.

$\mathrm{Az}$ eltérō távolságértelmezések és az eltérö súlyok használata ellenére mindhárom modell felmutat közös vonásokat. Egyrészt a csatolt települések (Györszentiván, Ménföcsanak és Gyirmót, Kisbácsa és Bácsa) kapcsolatai a város belsỏ területeivel, illetve egymással nagyon alacsony intenzitásúak, esetlegesek. Csak a harmadik modellszámításban érte el a legalacsonyabb, de még szignifikánsnak tekintett kapcsolati erösséget a belváros felé történő vonzódásuk. 


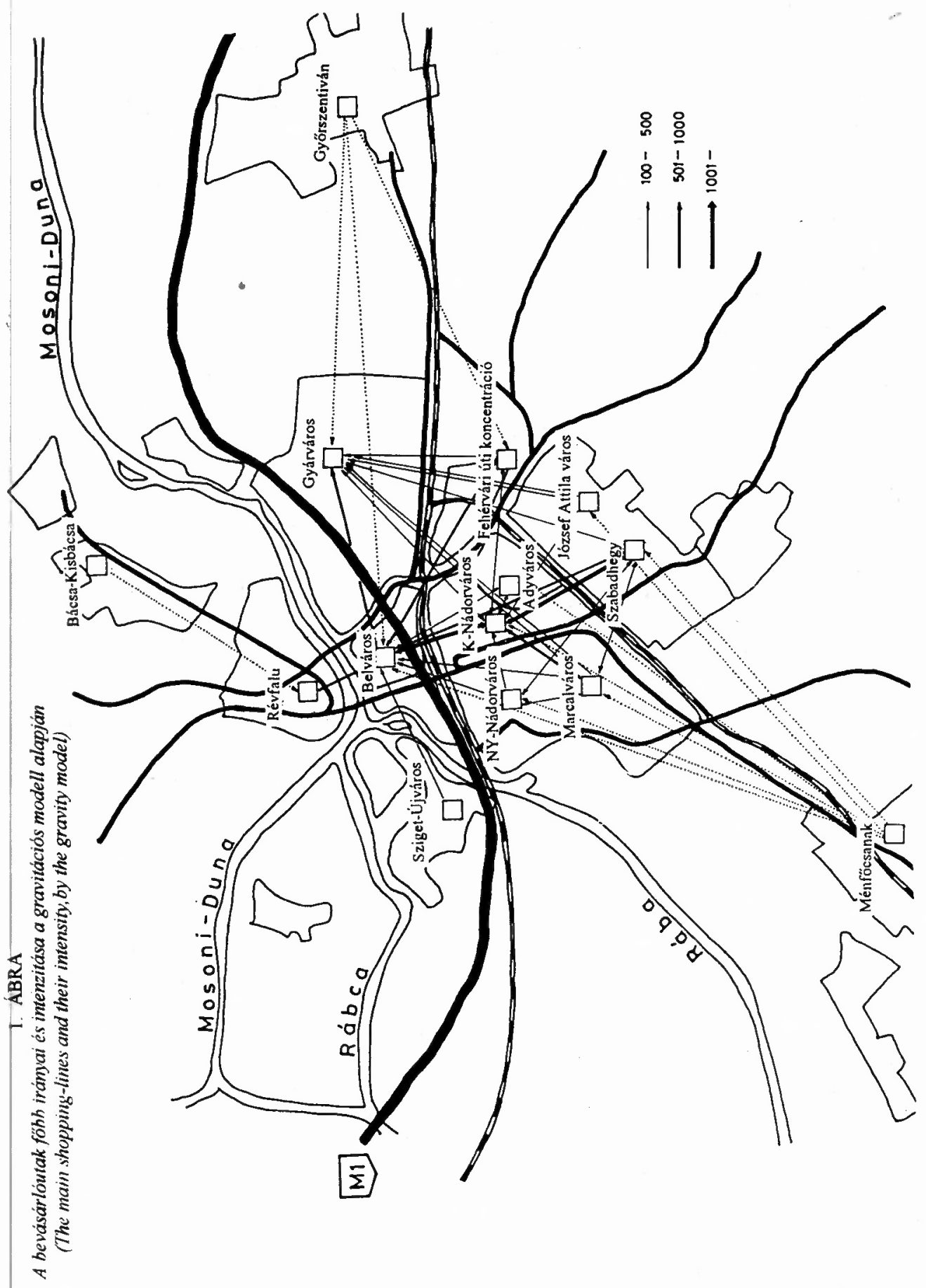


Második közös vonásként említhetó, hogy minden számítás szerint a belváros rendelkezik a többi városrész felé a legjelentősebb vonzerővel, $s$ a csatolt településeket leszámítva minden városrésszel mindhárom modellben a szignifikánsnak tekintett szint feletti vonzásértékek adódtak. A belvárostól távolodva a vonzás intenzitása általában csökken, kivéve, ha nagyon jó a két városrész tömegközlekedési kapcsolata, vagy a számolásban használt súlyok nagyon erösek.

A belváros és a csatolt települések kőzötti várostesten belül formálódó szubcentrumnak adódott mindhárom modellben a Nádorváros - ennek is föként a keleti része -, mely szinte minden városrész lakói számára jól elérhetỏ, kiskereskedelmi forgalma, vagy az egységek alapterülete jelentös, a kiskereskedelem struktúrája változatos. A városrész föként társasházi beépítése és kedvező intézményi ellátottsága miatt is vonzó a kereskedők számára. Ráadásul a városrész peremén található az egyik jelentős kereskedelmiszolgáltatási szubcentrum is.

A túlnyomórészt lakótelepi beépítésủ Adyváros, József Attila város és Marcalváros kapcsolatrendszerében a helyi lakosság külső bevásárlásai a döntóek. Önálló centrum szerepük nincs, ezt bizonyítja, hogy egymás között - a viszonylag csekély távolság és a jó megközelíthetőség ellenére - csak alacsony intenzitású kapcsolatok álnak fenn. A marcalvárosi lakosság bevásárlóútjai azonban feltehetően megváltoztak az utóbbi egy-két évben az itt kialakított kereskedelmi szubcentrum miatt. (Ebben kisebb üzletek és nagy alapterületú élelmiszer-áruházak is helyet kaptak.)

A belvároshoz csatlakozó, de attól folyókkal elválasztott Révfalu, illetve Sziget-Újváros városirészek szinte kizárólag a belvároshoz kötődnek, a távolabbi városrészekkel a kapcsolataik nagyon alacsony intenzitásúak. $\mathrm{Az}$ összeépült várostest peremén elhelyezkedó újonnan alakult/alakuló kiskereskedelmi koncentrációk: a funkcionális homogenitását levetköző Gyárváros, a hasonló utat bejáró Fehérvári úti koncentráció, valamint a kertvárosi jellegét vegyes funkcióra cserélö Szabadhegy és a hozzájuk csatlakozó városrészek kapcsolatrendszere elsősorban a hozzájuk térben legközelebb elhelyezkedő városrészekkel a legintenzívebb, térben távolodva az intenzitás mértéke folyamatosan csökken.

Az eltérő megközelítések természetesen lényeges különbségeket is mutatnak, ám ezt az eltérő számítási módokból következỏnek tartjuk.

A modellszámítások tanúsága szerint a kiskereskedelem által generált vonzások alapján Győr város térszerkezete az ideálisnak tekinthetö állapottól meglehetősen messze van. A belváros súlya a kiskereskedelmi célú mozgásokból túlságosan nagy, nem áll arányban a városrész kis területével, többirányú lezártságával, s a történelmi városmag fokozatos forgalom-mentesitésének szándékával.

A belvárossal érintkezö hagyományos lakóöv részének tekinthetỏ Nádorváros, Révfalu, illetve Sziget-Újváros lakossága túlnyomórészt a belvárosban végzi bevásárlásait. A nádorvárosi szubcentrum elsősorban a környék lakosait és a lakótelepieket vonzza. A kiskereskedelmi forgalom és alapterület kedvező mutatóinak elemzésénél pedig figyelembe kell vennünk az üzletek jellegét. Közülük sok a specializált (pl. számítástechnikai, irodatechnikai) üzlet, amelyek nem napi bevásárlóutak célpontjai.

A lakótelepeken a garázsboltok robbanásszerủ elterjedése ellenére a kiskereskedelmi célú bevásárlások jelentös része a városrészen kívül zajlik, önálló vonzáscentrumokká valószínủleg nagyobb távlatban sem válhatnak. Az apró üzletek a kisebb összegủ, napi két napi gyakoriságú élelmiszer-vásárlások szempontjából fontosak az itt élöknek. 
A peremeken és forgalmas csomópontokban formálódó kiskereskedelmi koncentrációk most is alakítják saját vonzásterületüket, ehhez a külföldi üzletláncok györi megjelenése is hozzájárul. (A legjelentősebb megvalósult beruházás a SPAR $10000 \mathrm{~m}^{2}$-es bevásárlóközpontja a Gyárváros belvároshoz közel eső peremén.) Megfigyelhetó a korábbi kizárólagosan nagykereskedelmi forgalmat bonyolító városperemi raktárvárosok (Szabadhegy, Fehérvári út, Gyárváros) részben kiskereskedelmi célú hasznositása. Ezek azonban nem alkotnak térben összefüggő tömörülést.

A csatolt települések kiskereskedelmi hálózata a jelenlegi struktúrájában elégtelen a helyi lakosság igényeinek kielégitésére, ezért itt a modellben számítottnál jóval erősebb kényszermozgások léteznek, melyek korábban a belvárost, újabban a nagyobb bevásárlócentrumokat veszik célba. E településrészek helyzetén javithatnak a tervezett bevásárlóközpont-építkezések (Győrszentivánon az autópálya csomópont közelében egy 10000 négyzetméteres, illetve Ménföcsanak közelében, szintén az autópálya csomópontnál egy óriás - $40000 \mathrm{~m}^{2}$-es - komplex bevásárló- és szolgáltató központ építését tervezik). A megcélzott vásárlói kör ezekben a projektekben elsősorban a személygépkocsin közlekedö lakosság, ezen belül is kiemelten a Bécs-Budapest autópályát igénybe vevők jelentős hányada. Természetesen a városi - és ezen belül a csatolt települések - lakosságának egy részét is szeretnék legalább a heti, vagy havi nagybevásárlások erejéig kicsábítani.

\section{A továbblépés irányai}

A modell alkalmazhatóságának, finomításának több lehetséges módja van. A városrészek tömegének meghatározásakor a forgalom és az alapterület mellett az üzletek árucsoportok szerinti megoszlását is figyelembe kellene venni, mert ez lehetôvé teszi a napi heti, vagy ritkább bevásárlóutak (hozzávetőleges) elkülönítését. Így a városrészek közötti kapcsolatok intenzitásáról pontosabb és árnyaltabb képet kapunk. A harmadik modellben a vonzott városrészek összlakosságával lakosságával számoltunk a tömeg meghatározásakor. Ennek pontosítása a jövedelmi viszonyok figyelembevételével, tehát a vásárlóeró meghatározásával lehetséges.

A súlypontok közötti távolság mérésére a tömegközlekedési eszközökkel és a személygépkocsival való elérhetőség kombinációja tủnik a legalkalmasabbnak. Ebben az esetben az átlagos haladási sebességet, $\mathrm{s}$ ehhez a város úthálózatának sérülékeny pontjait kell feltárni.

A továbblépés másik lehetósége a számítások elvégzése a hazai nagyvárosi hálózat más elemeire is. A százezres lakosságszámú városokban már bizonyosan kialakultak a kiskereskedelmi szempontból eltérő karaktert mutató városrészek.

További felhasználásra bátoríthat a modell matematikai apparátusának egyszerúsége, az eredmények azonnali átláthatósága is. Fontos megjegyezni azonban, hogy a többféle mutatóval történó számítás fontos feltétele annak, hogy a valóságot tükröző eredményeket kapjunk. Az első és második modell esetében a kiskereskedelmi egységek tömegével számoltunk, ám a módszer hibájául róható fel, hogy az üzletek nem egymást vonzzák. A harmadik modellben ezt ugyan sikerült kiküszöbölni, de ekkor kénytelenek voltunk figyelmen kívül hagyni a városrészen belüli üzletek vonzását. Márpedig az empirikus vizsgálatok szerint a györiek több, mint fele lakóhelye közelében intézi el napi bevásárlásait, közel $43 \%$-uk pedig munkahelye közelében. Ezek a mozgások, a közöttük fennálló kapcsolat további empirikus és matematikai-statisztikai vizsgálatokat igényelnek. 


\section{Irodalom}

Beluszky P. (1967) Die Kleinhandelscentren Ungars und ihre Anzielungsbereiche. Acta Geogr. Derbecina, Deberecen 80-82. 0.

Beluszky P. (1974) Nyíregyháza vonzáskörzete. Földrajzi Tanulmányok» 13. Akadémiai Kiadó, Budapest.

Beluszky P. (1981) A városi vonzäskörzetek (városkörnyékiség) vizsgálatának elvi módszertani kérdései. ÁSZI, Budapest.

Chojnicki Z. - Wrobel A. (1963) Matematikai-statisztikai módszerek a gazdasági fóldrajzban. Földrajzi Értesíró 12. 379-392. 0 .

Dawson, J. A, (1982) Commercial Distribution in Europe. Croom Helm, London. 232. 0.

Erlander, S.-Stewart, N.F. (1980) The Gravity model in transportation analysis - theory and extensions. VSP, Utrecht.

Hansen W. G. (1959) How Accessibility Shapes Land Use. Journal of the American Institute of Planners, May 245-262. 0 .

Hoover E. M. (1971) An Introduction of Regional Economics. A. A. Knopf, New York.

Isard W. (1960) Methods of Regional Analysis. M.I.T. Press.

Karlquist, A.-Lundquist, L.-Snickars, F. (eds.) (1975) Dynamic allocation of urban space. Saxon House, Westmead.

Klein, K. E, (1991) Potenial for Retail Location: Theoretical Estimation and Empirical Evidence. Münchener Geographische Hefte 69. 9I-110.

Korcelli P. (1975) Urban Spatial Interaction Models in a Planned Economy: A Preliminary Appraisal. Presentation 15th Congress of ERSA, Budapest

Kostrubiec B. - Loboda J. - Zadozdzon A. - Zipser T. (1975) Application of Mathematical Methods in Analysing and Forecasting Development of a Settlement System. Presentation, RSA Seminar, Zakopane.

Lackó L., (1978) Települések vonzásterületének meghatározása egymásrahatási modell segítségével. Földrajzi Értesitó XXVII./1, 31-43. o.

Papp A. (1981) Deberecen vonzáskörzete. Alföldi Tanulmányok V. 177-204. o.

Reilly W. J. (I929) Methods for the Study of Retail Relationships. University of Texas Bulletin, No. 2944.

Sikos T. T. (szerk.) (1984) Matematikai és statisztikai módszerek alkalmazási lehetőségei a területi kutatásban. Földrajzi Tanulmảnyok 19. Akadémiai Kiadó, Budapest.

Thorvid C. A. (1963) Ett försök till indelming ov Sverige i ekonomista regioer. Statistiks Tidskrift.

Williams, H.C.W.L.-SENIOR, M.L. (1978) Accessibility, satial interaction and spatial benfit analysis of land use. In: Spatial interaction theory and planning models. North Holland, Amsterdam.

Wilson, A.G. (1974) Urban and Regional Models in Geography and planning. John Wiley and Sons, London.

Wilson, A.G. et. al. (1981) Optimalization in locational and transport analysis. Wiley and Sons, Chichester.

Munkánkhoz nagy segitséget nyújtott a Györ kereskedelmi szerepkörének változási irányai c. tanulmány, amely az MTA RKK NYUTI-ban készült.

\section{Absract}

In this study we make an attempt to apply the gravity modell, to reveal the reasons some types of movements inside the city. This model wants to show that in the retail trade in Györ how strong attractions are among the main parts of the city.

The results of our analysis shows that the internal structure of the city Gyor is rather far from an ideal one by the attraction generated the retali trade sector. The importance of the $\mathrm{CBD}$ is too big in the movements of retail trade intention. It's not suitable for the planned future of the inner city, which wants to exempt this district from the traffic. And this CBD is rather small, and restricted by the rivers and the railway.

There is some way to purify our modell. We must take the groups of commodities dissociate into consideration, because it give us a chance to separate the daily, weekly and rare shoppings, so we get a cleaner portrait about the intensity of connections among the main parts of the city. 